\title{
ABE6: MHC Class I A*0201-LLFGYPVYV-B7 TCR complex \\ Convergence diagnostics of internal energy
}

\author{
Georgios S.E. Antipas ${ }^{1 *}$, Nikolaos A. Ntallis ${ }^{1}$ and Konstantinos T. Karalis ${ }^{2}$ \\ ${ }^{1}$ Molecular Modelling Laboratory, Park Innovaare, $\mathrm{CH}-5234$ Villigen, Switzerland \\ ${ }^{2}$ Institute of Geological Sciences, University of Bern, CH-3012 Bern, Switzerland \\ *Email: gantipas@mmlpi.ch, Tel.+41(0)445862050
}

Keywords: Quantum Immunology, Major Histocompatibility Complex (MHC), peptide (p), T Cell Receptor (TCR), Molecular Dynamics (MD), Competing Mode Decomposition (CMD).

\begin{tabular}{|c|c|}
\hline $\begin{array}{l}\text { A. Study scope } \\
\text { Quantum Immunology } \frac{1-10}{} \\
\text { Protein short-range order (SRO) })^{11-27}\end{array}$ & $\begin{array}{l}\text { B. Methods } \\
\text { Molecular dynamics } \\
\text { Parameter set: CHARMM22 } \\
\text { Water model: TIP3P } \\
\text { Solvent padding: } 40 \AA \\
\text { Periodic boundary conditions: Yes } \\
\text { MD Ensemble: Isothermal-isobaric (NPT) } \\
\text { Room temperature (RT): } 25^{\circ} \mathrm{C} \\
\text { Physiological temperature (PT): } 37{ }^{\circ} \mathrm{C} \\
\text { Convergence diagnostics } \\
\text { Competing Mode Decomposition }\end{array}$ \\
\hline \multicolumn{2}{|l|}{$\begin{array}{l}\text { MHC sequence } \\
\text { GSHSMRYFFTSVSRPGRGEPRFIAVGY } \\
\text { HRVDLGTLRGYYNQSEAGSHTVQRMY } \\
\text { WEAAHVAEQLRAYLEGTCVEWLRRYL } \\
\text { DGEDQTQDTELVETRPAGDGTFQKWA }\end{array}$} \\
\hline $\begin{array}{l}\text { MHC mutations: None } \\
\text { Peptide gene/comments: TAX prote } \\
\text { Peptide sequence } \\
\text { LLFGYPVYV }\end{array}$ & uman T-lymphotropic virus type 1 \\
\hline \multicolumn{2}{|c|}{$\begin{array}{l}\text { QQVKQNSPSLSVQEGRIS I LNCDYTNSMFDYF LWYKKY PAEGPTFLIS ISS IKDKNADGRFTVFLNKSAKHLS } \\
\text { LHIVPSQPGDSAVYFCAAMEGAQKLVFGQGTRLT INPNIQNPDPAVYQLRDSKSS DKSVCLFTDFDSQTNVSQ } \\
\text { SKDSDVYITDKTVLDMRSMDFKSNSAVAWSNKS DFACANAFNNS I I PEDTFFPSPESS }\end{array}$} \\
\hline \multicolumn{2}{|c|}{$\begin{array}{l}\text { ICR-ß sequence } \\
\text { NAGVTQTPKFQVLKTGQSMTLQCAQDMNHEYMSWYRQDPGMGLRLIHYSVGAGITDQGEVPNGYNVSRSTTED } \\
\text { FPLRLLSAAPSQTSVYFCASSYPGGGFYEQYFGPGTRLTVTEDLKNVFPPEVAVFEPSEAEISHTQKATLVCL } \\
\text { ATGFYPDHVELSWWVNGKEVHSGVSTDPQPLKEQPALNDSRYALSSRLRVSATFWQDPRNHFRCQVQFYGLSE } \\
\text { NDEWTQDRAKPVTQIVSAEAWGRAD }\end{array}$} \\
\hline TCR- $\beta$ mutations: None & \\
\hline
\end{tabular}


a

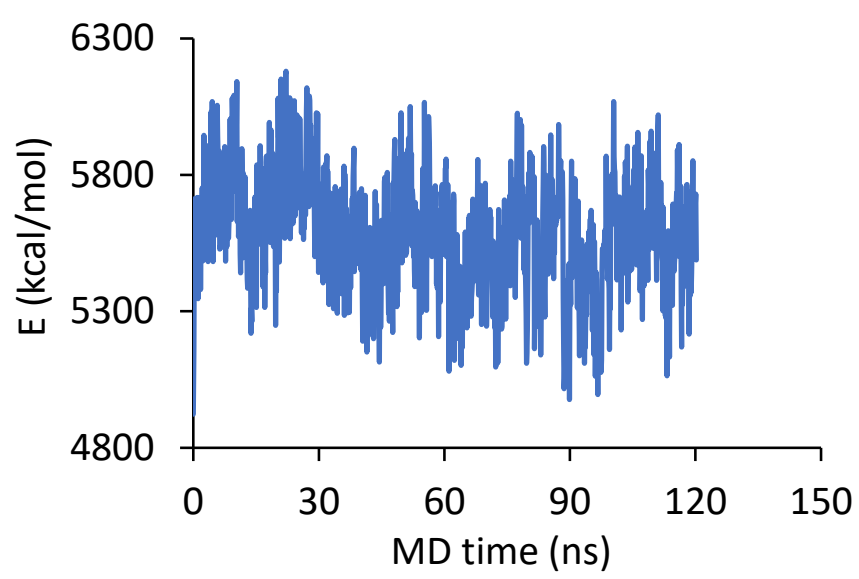

b

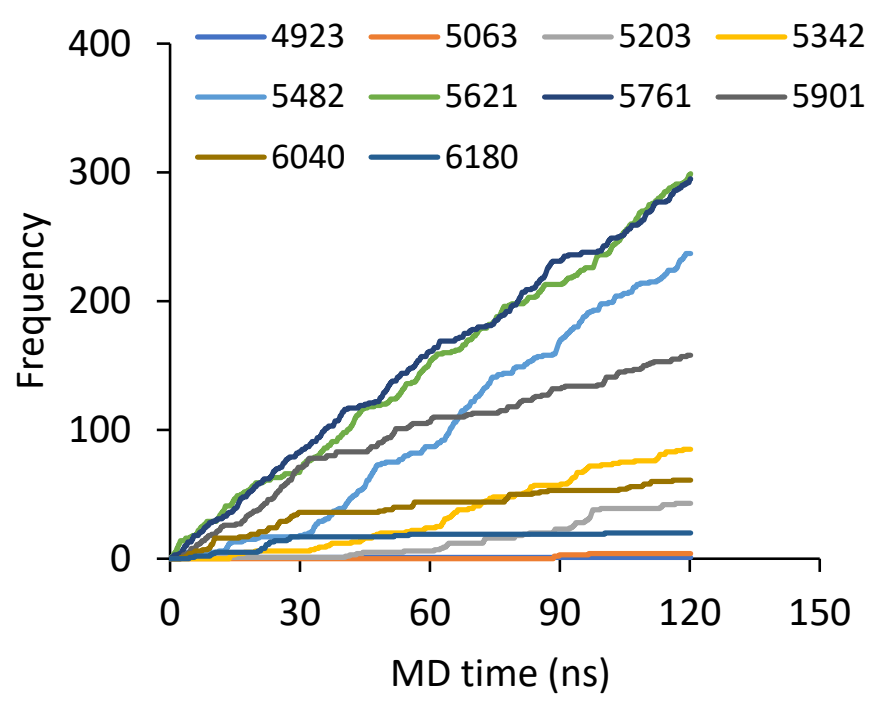

C

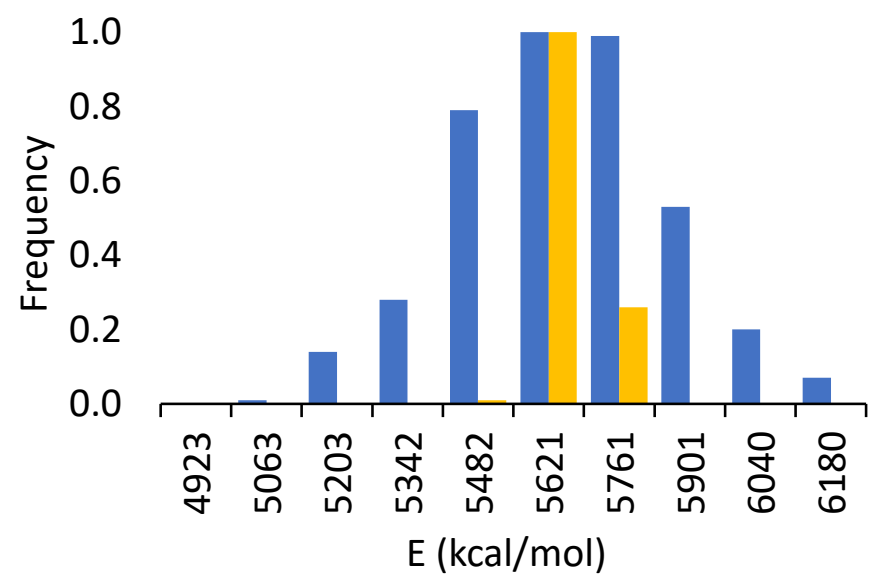

d

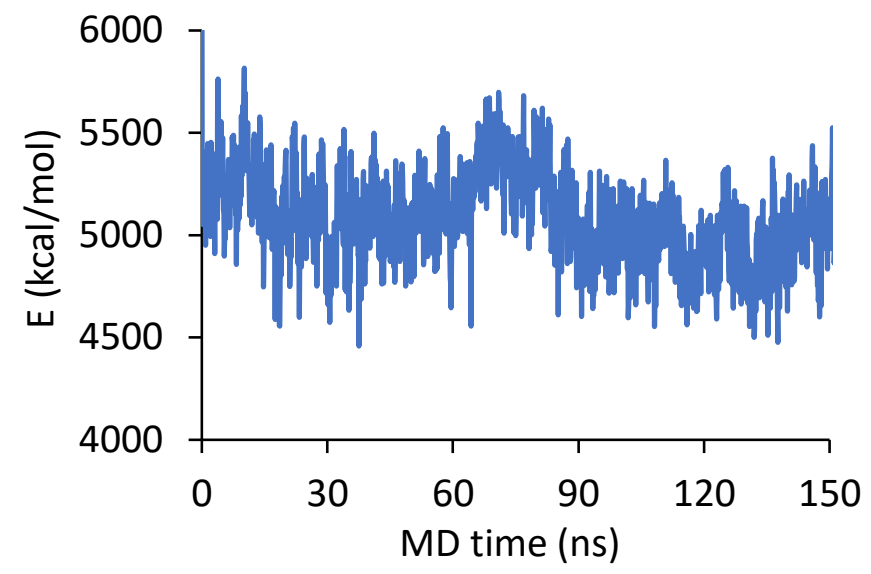

e

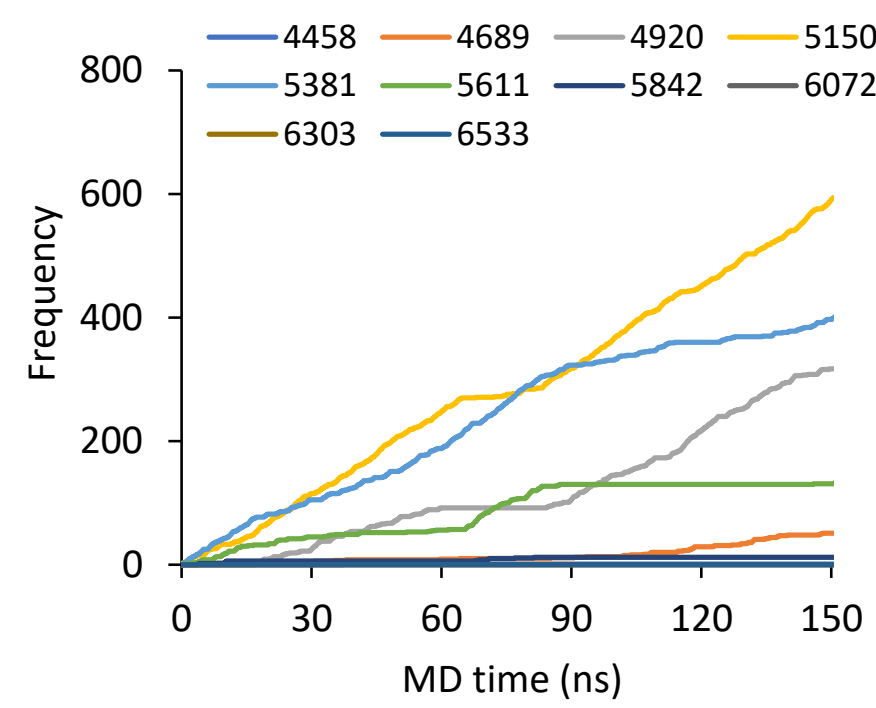

f

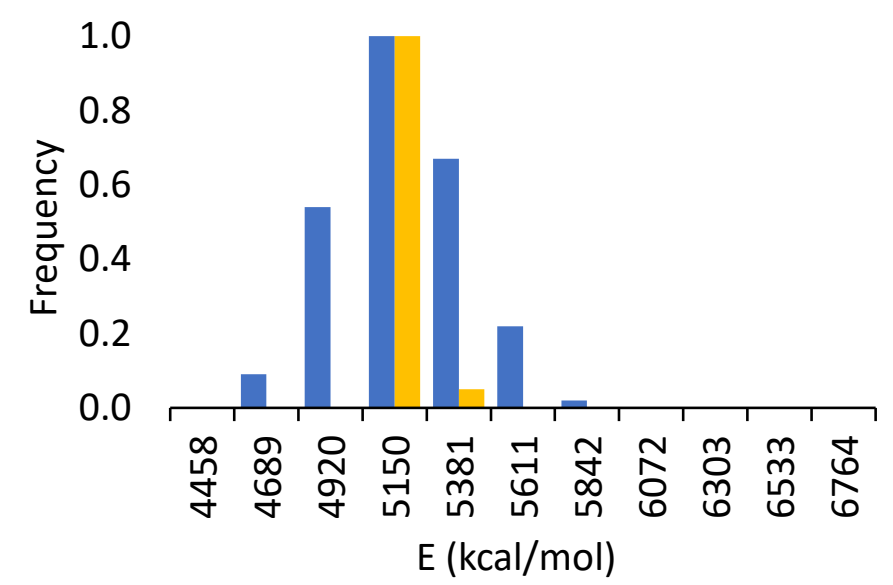

Figure 1. ABE6 supercell internal energy, E, vs. MD time for (a) RT and (d) PT. CMD convergence analysis of E vs. MD time for (b) RT and (e) PT. (c) Probability density function of the RT E trajectory (Fig.1a), blue bars, and of the RT E sample means (sample size of 30), yellow bars. (f) Probability density function of the PT E trajectory (Fig.1d), blue bars, and of the RT E sample means (sample size of 30), yellow bars. See Table 1 for convergence diagnostics. 
Table 1. Convergence diagnostics.

\section{Temperature: RT}

Time (ns): 104.4

Type: full

Residual time for full convergence (ns): None

Temperature: PT

Time (ns): 91.3

Type: full

Residual time for full convergence (ns): None 


\section{Conflict of interest}

It is declared that there is no conflict of interest.

\section{Author contributions}

Analysis was based on precursor theoretical modelling related to atomic and mesoscale systems $\frac{1-58}{}$.

\section{References}

1 Germenis, A. E., Manousakis, M. N. \& Antipas, G. S. E. The Dawn of Quantum Immunology. SRL Immunology and Immunotherapy 1, 3-6 (2016).

2 Antipas, G. S. E. \& Germenis, A. E. Atomic coordination reflects peptide immunogenicity. Frontiers in Molecular Biosciences 2, doi:10.3389/fmolb.2015.00077 (2016).

3 Antipas, G. S. E. \& Germenis, A. E. The coordination of unprotonated peptide tertiary structure as a metric of pMHC-TCR functional avidity. Data In Brief 5, 342-347, doi:10.1016/j.dib.2015.09.009 (2015).

4 Antipas, G. S. E. \& Germenis, A. E. Human Cytomegalovirus variant peptides adapt by decreasing their total coordination upon binding to a T cell receptor. Data In Brief 4, 492499, doi:10.1016/j.dib.2015.07.019 (2015).

5 Antipas, G. S. E. \& Germenis, A. E. The quantum chemical causality of pMHC-TCR biological avidity: peptide atomic coordination data and the electronic state of agonist $\mathrm{N}$ termini. Data In Brief 3, 180-184, doi:10.1016/j.dib.2015.02.021 (2015).

6 Antipas, G. S. E. \& Germenis, A. E. Quantum chemical calculations predict biological function: The case of T cell receptor interaction with a peptide/MHC class I. Frontiers in Chemistry 3, doi:10.3389/fchem.2015.00009 (2015).

7 Antipas, G. S. E. \& Germenis, A. E. in IUPHAR Immunopharmacology Section - 8th Biannual Meeting of the Hellenic Society of Basic \& Clinical Pharmacology (Athens, Greece, 2014).

8 Antipas, G. S. E., Ntallis, N. A. \& Karalis, K. T. MHC Class I A*0201-LLFGYPVYV-A6 TCR complex: Convergence diagnostics of internal energy and density. OSF Preprints, doi:10.31219/osf.io/sgwr5 (2020).

9 Antipas, G. S. E., Ntallis, N. A. \& Karalis, K. T. MHC Class I A*0201-LLFGYPRYV-A6 TCR complex: Convergence diagnostics of internal energy and density. OSF Preprints, doi:10.31219/osf.io/tjxzw (2020).

10 Antipas, G. S. E., Ntallis, N. A. \& Karalis, K. T. MHC Class I A*0201-LLFGYAVYV-A6 TCR complex: Convergence diagnostics of internal energy and density. OSF Preprints, doi:10.31219/osf.io/h5a32 (2020).

11 Antipas, G. S. E. \& Ntallis, N. A Relaxation Time-Approximation method for the efficient detection of critical states in reactive trajectories. OSF Preprints, doi:10.31219/osf.io/8vnm7 (2020).

12 Antipas, G. S. E. \& Karalis, K. T. Direct determination of amorphous number density from the reduced pair distribution function. MethodsX 6, 601-605, doi:10.1016/j.mex.2019.03.005 (2019).

13 Karalis, K. T., Dellis, D., Antipas, G. S. E. \& Xenidis, A. Bona-fide method for the determination of short range order and transport properties in a ferro-aluminosilicate slag. Scientific reports 6, 30216, doi:10.1038/srep30216 (2016).

14 Antipas, G. S. E., Mangiorou, E. \& Hristoforou, E. The effect of Indium content on the atomic environment and cluster stability of $\mathrm{GeSe}_{4} \mathrm{In}_{\mathrm{x}=10,15}$ metallic glasses. Metals 5, 102-118, doi:10.3390/met5010102 (2015).

15 Antipas, G. S. E. Formation energies associated to the growth, inter-diffusion and surface alloying of $\mathrm{Cr}$ and $\mathrm{Nb}$ single layers on a pure Cu substrate. Annals of Materials Research (2015).

16 Antipas, G. S. E. A concise methodology for the estimation of elemental concentration effects on mesoscale cohesion of non-ferrous covalent glasses: the case of $\mathrm{Se}_{(80-\mathrm{x})} \mathrm{Ge}_{(20-}$ x) $\mid \mathrm{n}_{\mathrm{x}=0,5,10,15 .}$. Data In Brief 4, 257-265, doi:10.1016/j.dib.2015.05.024 (2015). 
17 Statharas, E., Tserotas, P. \& Antipas, G. S. E. Experimental and First Principles' Characterization of Functionalized Magnetic Nanoparticles. Key Engineering Materials 605, 681-684, doi:10.4028/www .scientific.net/KEM.605.681 (2014). constrained atomic order probing of a Si-Al composite glass. Philosophical Magazine, 1-9, doi:10.1080/14786435.2013.863438 (2014).

19 Antipas, G. S. E., Papassiopi, N. \& Xenidis, A. On the elusive anti-bayerite structure. Solid State lonics 255, 65-73, doi:10.1016/j.ssi.2013.11.052 (2014).

20 Antipas, G. S. E., Mangiorou, E. \& Hristoforou, E. Solute-solvent interactions and atomic cohesion in $\mathrm{GeSe}_{4}$ and $\mathrm{GeSe}_{4} \mathrm{In}_{5}$ metallic glasses. Materials Research Express 1, 015202, doi:10.1088/2053-1591/1/1/015202 (2014).

21 Antipas, G. S. E. \& Mangiorou, E. Atomic topology and electronic structure of a melt-spun $\mathrm{Al}_{92} \mathrm{U}_{8}$ metallic glass. Computational and Theoretical Chemistry 1036, 16-21, doi:10.1016/j.comptc.2014.03.009 (2014).

22 Antipas, G. S. E. \& Karalis, K. The effect of annealing on the electronic stability of an amorphous $\mathrm{Zr}_{70} \mathrm{Pd}_{30}$ alloy. Materials Chemistry and Physics 147, 1092-1098, doi:10.1016/j.matchemphys.2014.06.063 (2014).

23 Antipas, G. S. E. Short range order and stability of a mechanically alloyed $\mathrm{Cr}_{25} \mathrm{Nb}_{75}$ alloy determined by total scattering and first principles. Materials Research 17, 1677-1685, doi:10.1590/1516-1439.323014 (2014).

24 Antipas, G. S. E., Temleitner, L., Karalis, K., Pusztai, L. \& Xenidis, A. Atomic order and cluster energetics of a 17 w.t.\% Si-based glass versus the liquid phase. Journal of Physics: Condensed Matter 25, 1-7, doi:10.1088/0953-8984/25/45/454206 (2013).

25 Antipas, G. S. E., Statharas, E., Tserotas, P., Papadopoulos, N. \& Hristoforou, E. Experimental and First-Principles Characterization of Functionalized Magnetic Nanoparticles. ChemPhysChem 14, 1934-1942, doi:10.1002/cphc.201300161 (2013).

26 Antipas, G. S. E. Molecular orbital interactions in glass-forming $\mathrm{Zr}_{70} \mathrm{Cu}_{30}$ liquid quasicrystals. Journal of Alloys and Compounds 578, 565-570, doi:10.1016/j.jallcom.2013.06.179 (2013).

27 Antipas, G. S. E. et al. A containerless study of short-range order in high-temperature Fe-SiAl-Ca-Mg-Cr-Cu-Ni oxide systems. Journal of Molecular Structure 1019, 151-158, doi:10.1016/j.molstruc.2012.03.056 (2012).

28 Karalis, K., Karalis, N., Karkalos, N., Antipas, G. \& Xenidis, A. Computational fluid dynamics analysis of a three-dimensional electric submerged arc furnace operation. OSF Preprints, doi:10.31219/osf.io/xgnse (2020).

29 Antipas, G. S. E., Ntallis, N. A. \& Karalis, K. T. MHC Class I H-2Kb-INFDFNTI-BM3.3 TCR complex: Convergence diagnostics of internal energy and density. OSF Preprints, doi:10.31219/osf.io/tp78g (2020).

30 Antipas, G. S. E., Ntallis, N. A. \& Karalis, K. T. MHC Class I A*0201-LLFGYPVYV-B7 TCR complex: Convergence diagnostics of internal energy and density. OSF Preprints, doi:10.31219/osf.io/yzces (2020).

31 Antipas, G. S. E. \& Karalis, K. T. Direct determination of amorphous number density from the reduced Pair Distribution Function. OSF Preprints, doi:10.31219/osf.io/n7gk9 (2020).

32 Karalis, K., Karkalos, N., Antipas, G. S. E. \& Xenidis, A. Pragmatic analysis of the EAF continuum. Royal Society Open Science, doi:10.1098/rsos.170313 (2017).

33 Karalis, K. et al. A CFD analysis of slag properties, electrode shape and immersion depth effects on electric submerged arc furnace heating in ferronickel processing. Applied Mathematical Modelling, doi:10.1016/j.apm.2016.05.045 (2016).

34 Karalis, K., Karkalos, N., Antipas, G. S. E. \& Xenidis, A. in Metal 2015.

35 Antipas, G. S. E. Improvement of the micro-hardness and wear resistance of various light alloys by plasma-sensitization. Annals of Materials Research (2015).

36 Antipas, G. S. E. Plasma-driven mechanisms of the surface modification of an Al6061 alloy. Annals of Materials Research (2015).

37 Antipas, G. S. E. Experimental and first principles assessment of plasma attenuation during laser treatment of an Al alloy. Transactions of the IMF 93, 53-56, doi:10.1179/0020296714Z.000000000226 (2015). 

Annals of Materials Research (2015).

39 Papassiopi, N. et al. A XAFS study of plain and composite iron(III) and chromium(III) hydroxides. Chemosphere 111, 169-176, doi:10.1016/j.chemosphere.2014.03.059 (2014). Antipas, G. S. E. \& Statharas, E. Surface properties of a laser-irradiated Al 6061 alloy. International Journal of Computational Materials Science and Surface Engineering 6, 1-12, doi:10.1504/IJCMSSE.2014.063755 (2014).

41 Antipas, G. S. E. Mechanical properties of a particle-reinforced Zr bulk metallic glass. International Journal of Materials 1, 149-151 (2014).

42 Antipas, G. S. E. Plasma-spray synthesis and characterization of Ti-based nitride and oxide nanogranules. Materials Research, 0-0, doi:10.1590/1516-1439.252013 (2014).

43 Antipas, G. S. E. Surface growth and diffusion energetics of Ag monolayers on $\mathrm{Cu}(001)$. Metals 4, 108-117, doi:10.3390/met4020108 (2014).

44 Antipas, G. S. E. Augmentation of wear-protective coatings for non-ferrous alloys by the addition of $\mathrm{Cr}$ and Ni elements. Materials Research, doi:10.1590/1516-1439.211013 (2014). Antipas, G. S. E. A mass efficiency test of $\alpha-\beta$ processed Ti-Al-V alloys. Key Engineering Materials 605, 605-608, doi:10.4028/www .scientific.net/KEM.605.605 (2014).

46 Papassiopi, N., Vaxevanidou, K., Christou, C., Karagianni, E. \& Antipas, G. S. E. Synthesis, characterization and stability of $\mathrm{Cr}(\mathrm{III})$ and $\mathrm{Fe}(\mathrm{III})$ hydroxides. Journal of hazardous materials, doi:10.1016/j.jhazmat.2013.09.058 (2013).

47 Antipas, G. S. E. The Effect of Increasing Sn Content on High-Temperature Mechanical Deformation of an Mg-3\%Cu-1\%Ca Alloy. Metals 3, 337-342, doi:10.3390/met3040337 (2013).

48 Antipas, G. S. E. Review of gas atomization and spray forming phenomenology. Powder Metallurgy, doi:10.1179/1743290113Y.0000000057 (2013).

49 Antipas, G. S. E. et al. in RMC5 (Budapest, Hungary, 2012).

50 Antipas, G. S. E. Spray forming of al alloys: Experiment and theory. Materials Research 15, 131-135, doi:10.1590/S1516-14392012005000007 (2012).

51 Antipas, G. Gas Atomization of Aluminium Melts: Comparison of Analytical Models. Metals 2, 202-210, doi:10.3390/met2020202 (2012).

52 Antipas, G. S. E., Lekakou, C. \& Tsakiropoulos, P. Microstructural characterisation of Al-Hf and $\mathrm{Al}-\mathrm{Li}-\mathrm{Hf}$ spray deposits. Materials Characterization 62, 402-408, doi:10.1016/j.matchar.2011.02.001 (2011).

53 Antipas, G. S. E. Liquid column deformation and particle size distribution in gas atomisation. International Journal of Computational Materials Science and Surface Engineering 4, 247264, doi:10.1504/IJCMSSE.2011.042822 (2011).

54 Antipas, G. S. E. Modelling of the break up mechanism in gas atomization of liquid metals Part II. The gas flow model. Computational Materials Science 46, 955-959, doi:10.1016/j.commatsci.2009.04.046 (2009).

55 Antipas, G. S. E. Modelling of the break up mechanism in gas atomization of liquid metals. Part I: The surface wave formation model. Computational Materials Science 35, 416-422, doi:10.1016/j.commatsci.2005.03.009 (2006).

56 Antipas, G. S. E. Mathematical modeling of metal spray forming. (original manuscript Oxford, 1998. Published as eBook, National Library of Greece) ISBN 978-618-80686-1-2, 1998).

57 Hunt, J. D., Antipas, G. \& Thomas, R. W. Alloy: solidification modeling. (1996).

58 Antipas, G., Lekakou, C. \& Tsakiropoulos, P. The break up of melt streams by high pressure gases in spray forming. Proceedings of the Second International Conference on Spray Forming, 15-24 (1993). 